\title{
EARTHQUAKE ORIGIN OF SUPERGLACIAL DRIFT ON THE GLAGIERS OF THE MARTIN RIVER AREA, SOUTH-GENTRAL ALASKA
}

By S. J. Tuthill

(Department of Geology and Geography, Muskingum College, New Concord, Ohio, U.S.A.)

Martin River Glacier and a small glacier for which the informal name "Sioux Glacier" will be used here (Fig. I ; lat. $60^{\circ} 24^{\prime}$ to $60^{\circ} 35^{\prime}$ N., long. I $43^{\circ} 30^{\prime}$ to I $44^{\circ} 25^{\prime}$ W.) are mantled with large quantities of rock debris. A series of photographs dating from I $93^{8}$ to 1964 and the geomorphic modifications resulting from the Alaskan earthquake (27 March 1964) suggest rock avalanching as an origin for much of the superglacial drift.

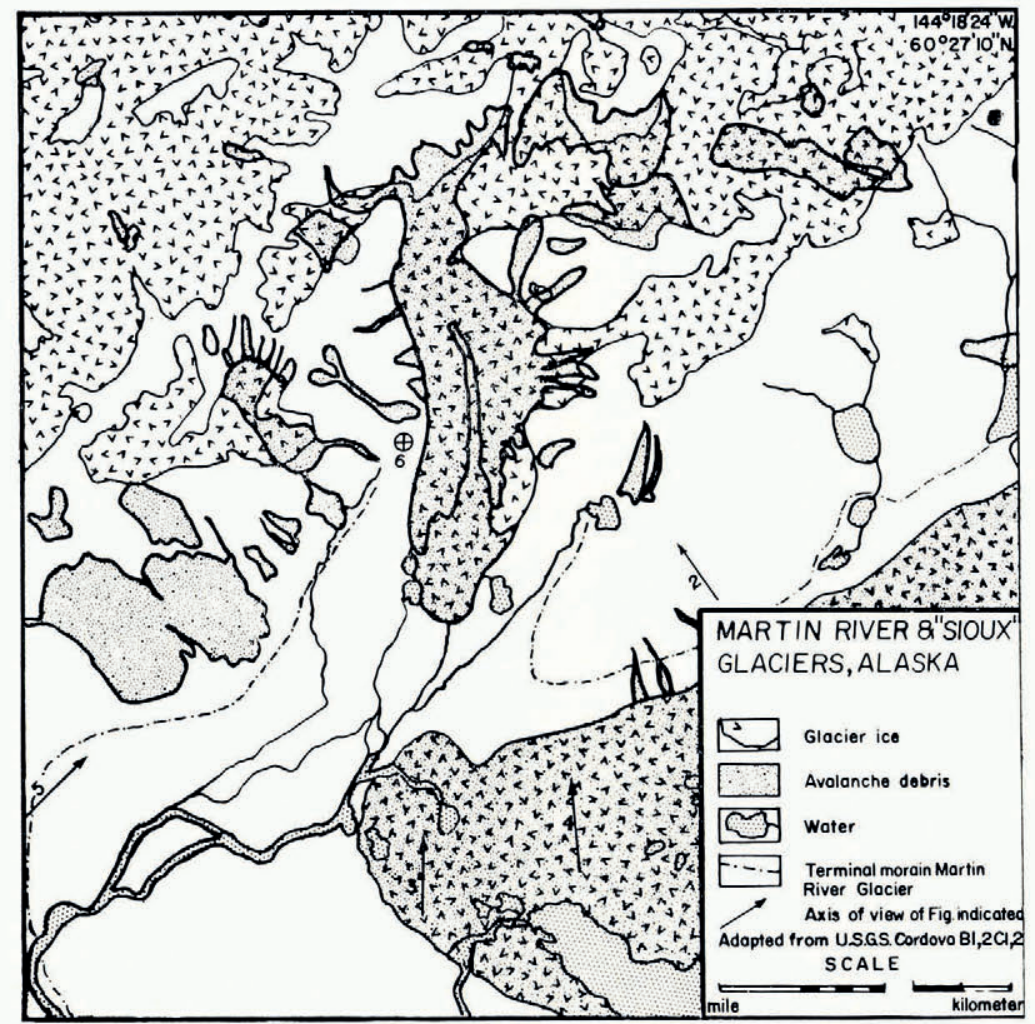

Fig. I. Map of the Martin River and "Sioux" Glaciers area, south-central Alaska. Adapted from the U.S. Geological Survey I: 63,360 Topographic Series, Cordova $B_{1}, B_{2}, C_{I}$ and $C_{2}$ quadrangles. Approximate headings of views of Figures 2-6 are shown

The drift on both of these glaciers is predominantly angular in shape and ranges from very large boulders to clay in grain-size.

Shear planes are frequently exposed in the sides of ice-walled sink-hole lakes in the terminus of Martin River Glacier. Only rarely are cobble-sized rocks observed in these shear planes, and in two summers of field explorations only one boulder was observed. This lack of large-sized rock fragments and the slight degree of rounding of the superglacial drift casts doubt on the idea that a significant part of the larger grain-sized superglacial debris is shear moraine. 
Martin River Glacier is intermediate between a valley glacier and a piedmont glacier, and it has more than 20 tributaries. A band of stagnant ice at the terminus indicates that the glacier is currently shrinking. The presence of a large amount of rock debris on the glacier surface could be attributed to the terminal concentration of debris from a large number of medial moraines. If nothing more than normal mass wasting along the tributary valley walls was envisioned as the main mechanism of delivery of rock material to the glacier, a protracted period of time would be required to concentrate the great amounts of debris now found on Martin River and "Sioux" Glaciers. The lateral distribution of material from the medial moraines near the present terminus of Martin River Glacier could be attributed to diversion of glacier ice by irregularities in the subglacial surface.

"Sioux Glacier" is a valley glacier about 8 miles $(12.9 \mathrm{~km}$.) in length. At one time it flowed around a large nunatak but now it is restricted to the west side of this feature. Its source is bifurcate and one small tributary glacier joins it near the terminus. The prominent medial moraine (Figs. 2, 3 and 4 ) is a very thinly covered ice ridge north of the broad terminal band of debris. The crest of the medial moraine was approximately $30-70 \mathrm{ft}$. $(9 \cdot \mathrm{I}-2 \mathrm{I} \cdot 3 \mathrm{~m}$.$) above$ the ice surface which lay on either side in August 1963 .

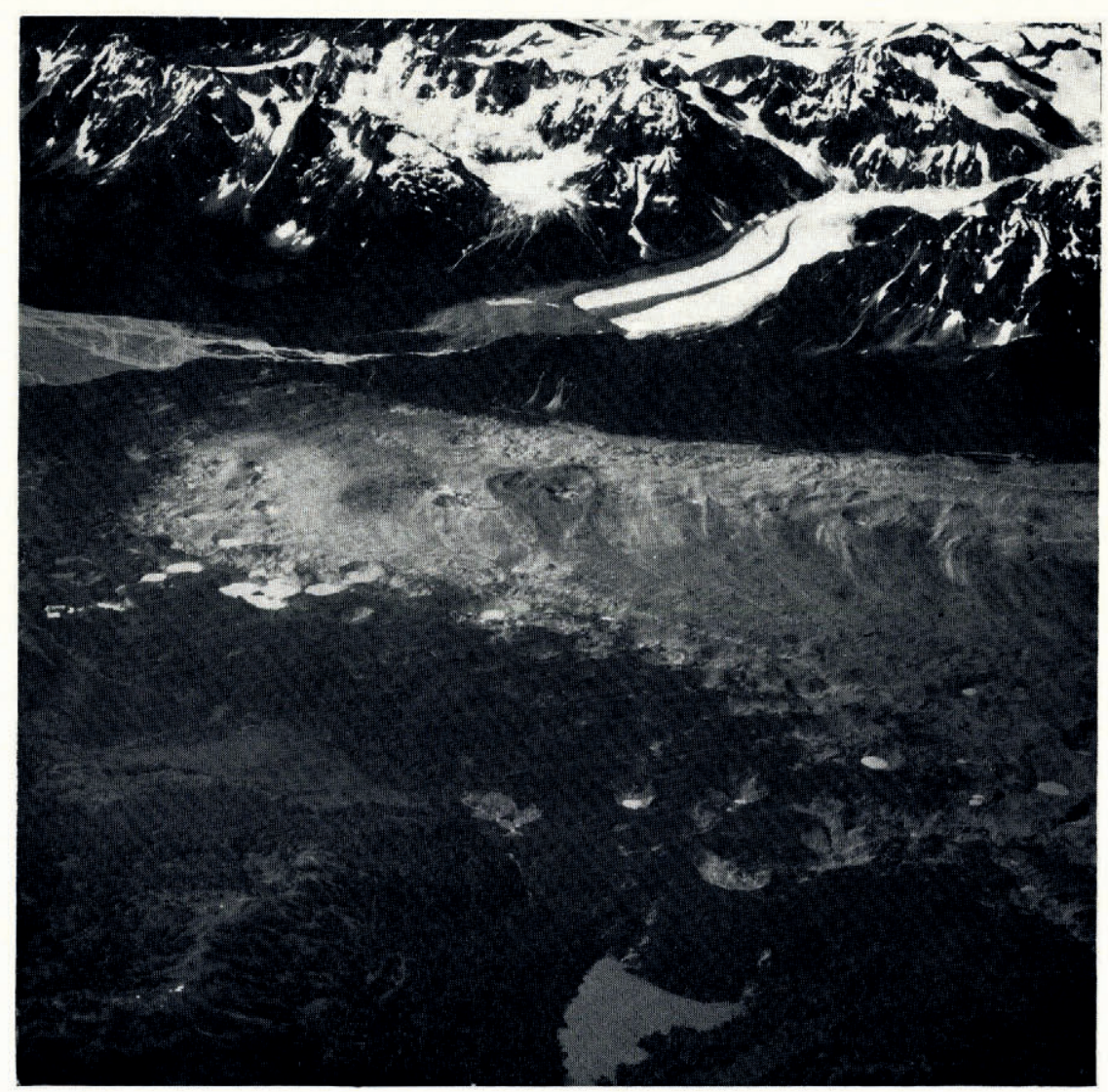

Fig. 2. Oblique aerial photograph of Martin River and "Sioux" Glaciers taken from over Charlotte Ridge and viewed towards the north-north-west. Deadwood Lake (left foreground) and "Bee Lake" (center foreground) mark the present ice margin of Martin River Glacier. Note the discrete debris avalanche deposit on the proximal side of the end moraine of "Sioux Glacier", transverse to the medial moraine. The large lateral moraine on the west margin of the glacier traces proximally to the couloir from which the debris issued. Three ridges on the distal side of the debris avalanche mentioned above may also be of the same origin. (Photograph by Bradford Washburn; No. 976, Boston Museum of Science, 1938) 


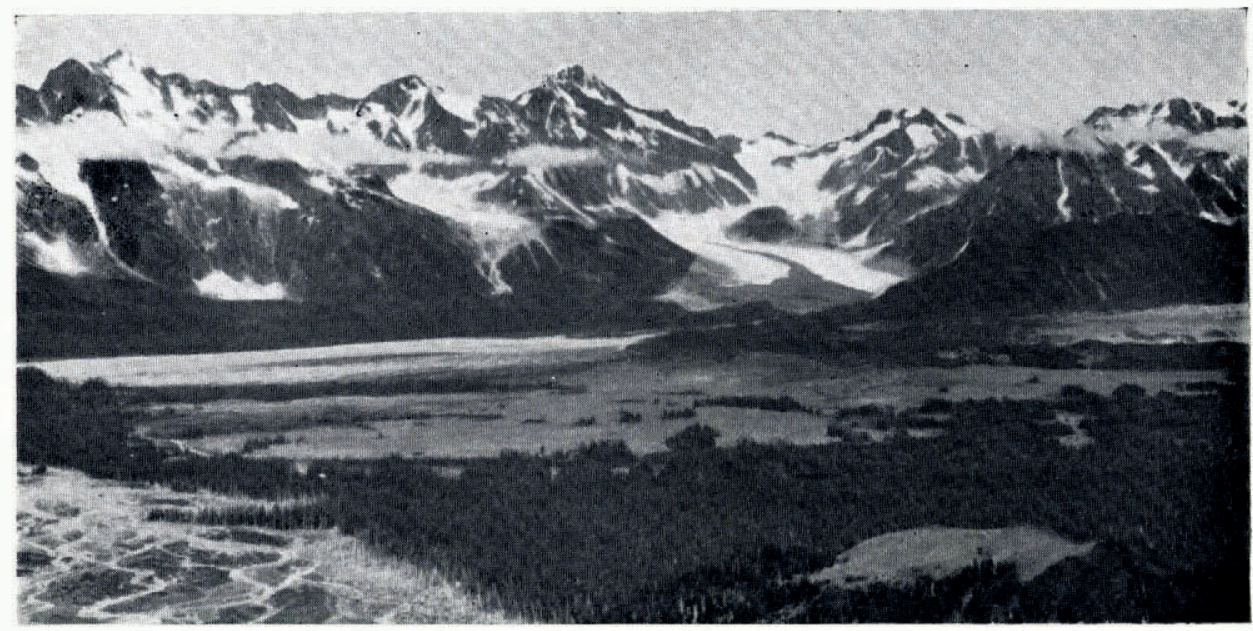

Fig. 3. Oblique photograph taken from the hill north of Tokun Lake of the terminal moraine (lefi) and current ice margin (right center) of Martin River and "Sioux" Glaciers, viewed towards the north. Debris avalanche material and the west lateral moraine of "Sioux Glacier" have dispersed laterally during the $7 \mathrm{yr}$. which elapsed between this and that shown in Figure 2. (Photograph by Don 7. Miller; No. 259, U.S. Geological Survey, 1945)

At the time of the Alaskan earthquake very large snow and rock avalanches descended upon both Martin River and "Sioux" Glaciers. While there were no witnesses to these avalanches, a similar avalanche occurred on Sherman Glacier 26 miles $(4 \mathrm{I} \cdot 8 \mathrm{~km}$.) to the west in a comparable geomorphic and geologic setting. The Sherman Glacier debris avalanche was heard to occur shortly after the earthquake commenced. In conjunction with the widespread snow and rock avalanches observed by geologists who flew over the area within a week after the earthquake (personal communication from George Plafker, U.S. Geological Survey), it is thus reasonable to assume that the avalanches in the Martin River area also occurred during the maximum intensity of the earthquake.

The material in these avalanches was spread over $\mathrm{I} \cdot 2 \mathrm{miles}^{2}\left(3 \cdot \mathrm{I} \mathrm{km} .^{2}\right)$ of the surface of "Sioux Glacier" and more than 4 miles $^{2}\left(10.4 \mathrm{~km}^{2}\right)$ of Martin River Glacier (Figs. 5,6 and 7).

An oblique aerial photograph taken in $193^{8}$ by Bradford Washburn (Curator, Museum of Science, Boston, Mass., U.S.A.) shows one distinct rock avalanche which bombarded the glacier from the couloir west of the nunatak and which was subsequently carried by the glacier flow, essentially intact, to the terminus (Fig. 2). The three ridges of rock debris, distal to the one mentioned above, also appear to have been discrete rock avalanche bodies which occurred previously.

An oblique photograph taken from a hill north of Lake Charlotte in 1945 by Don J. Miller of the U.S. Geological Survey (Fig. 3) shows the termini of Martin River Glacier and "Sioux Glacier". The debris avalanches have lost their form and appear as a medial moraine which has spread out at the terminus.

An oblique aerial photograph of "Sioux Glacier", taken for the University of Washington in 1960 by Austin Post (now of the U.S. Geological Survey), shows the further dispersion of the debris avalanche material and stagnation of the glacial terminus. The increase in the amount of rock debris at the glacier margin attributable to terminal distribution of material 


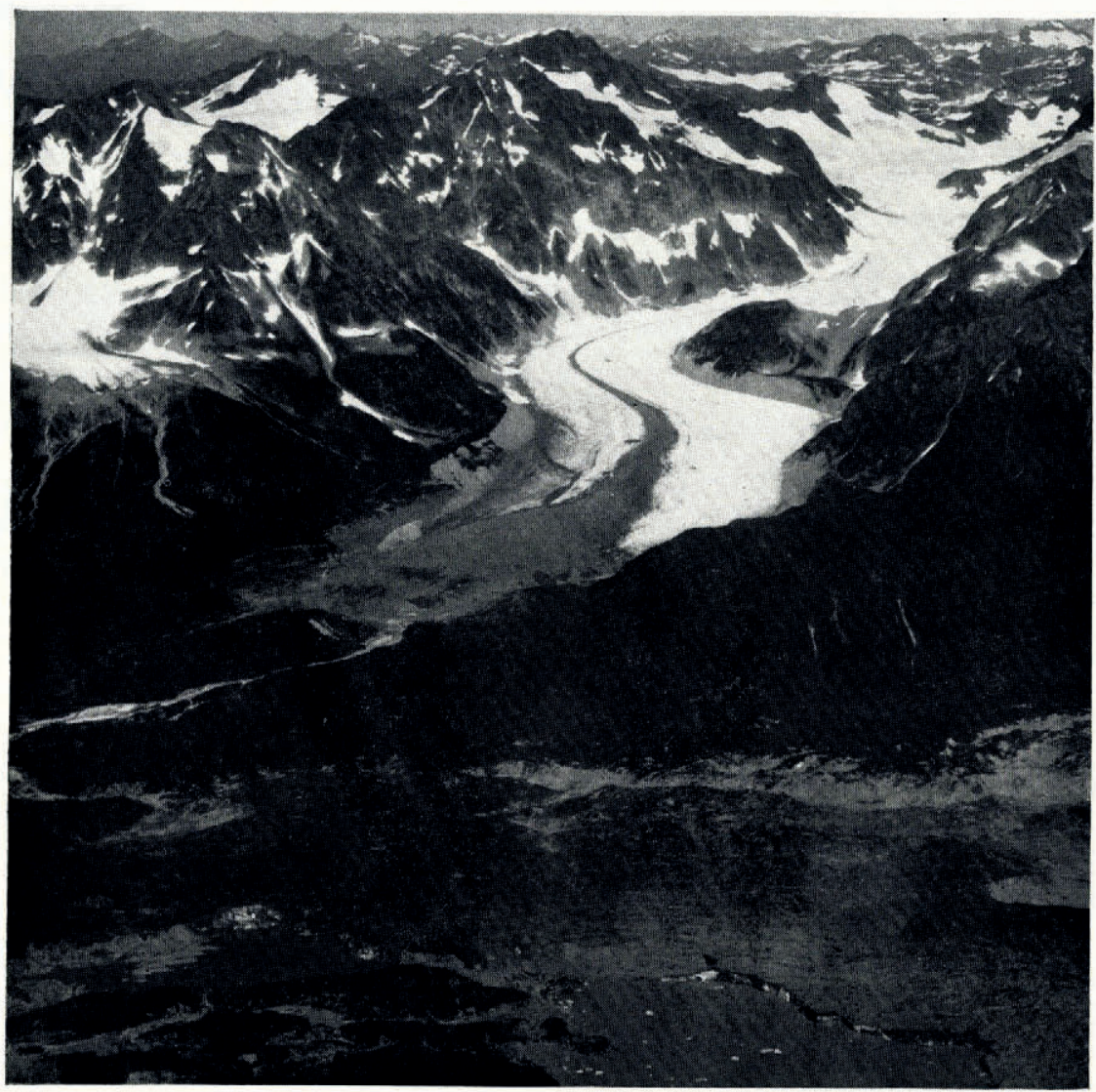

Fig. 4. Oblique aerial photograph of the current ice margin of Martin River and "Sioux" Glaciers taken from over Deadwood Lake and viewed towards the north-north-west. "Miller Lake" in the foreground is ice-walled on its north margin and has driftinsulated stagnant ice on its south margin. The lateral distribution of the rock debris of the terminus and of the west lateral moraine on "Sioux Glacier" gives no clue to the debris avalanche origin of the superglacial drift. "Miller Lake" is a coalesced group of the ice-walled sink-hole lakes seen in Figure 2. (Photograph by Austin Post, University of Washington, Seattle, Washington, 1960 )

from the medial moraine during the $22 \mathrm{yr}$. between the 1938 and 1960 photographs is very slight, but the distortion of the terminal debris by superglacial topographic inversion, resulting from insulation effects of the rock debris and movement of the glacier ice, appears to credit the medial moraine with delivery of all of the rock on the terminus.

Post photographed both "Sioux" and Martin River Glaciers in August 1964 (Figs. 6-7). These photographs reveal that "Sioux Glacier" was loaded with an estimated i $1 \times 10^{6} \mathrm{yd}^{3}$ $\left(8.3 \times 10^{6} \mathrm{~m} .{ }^{3}\right)$ of snow and rock debris. This estimate is based on observations made on the lower one-third of the glacier. Investigation of the upper part of the glacier was prevented by almost continuous fall of rock debris during the month of June 1964 .

The five large snow and rock avalanches on Martin River Glacier (Fig. 7) will be a considerable time in transit to the terminus. In addition to the rock debris and the avalanche snow which accompanied the rock falls of 27 March 1964 , glacier ice will be conserved by the insulating effect of the mantle of rock debris. W. O. Field of the American Geographical 


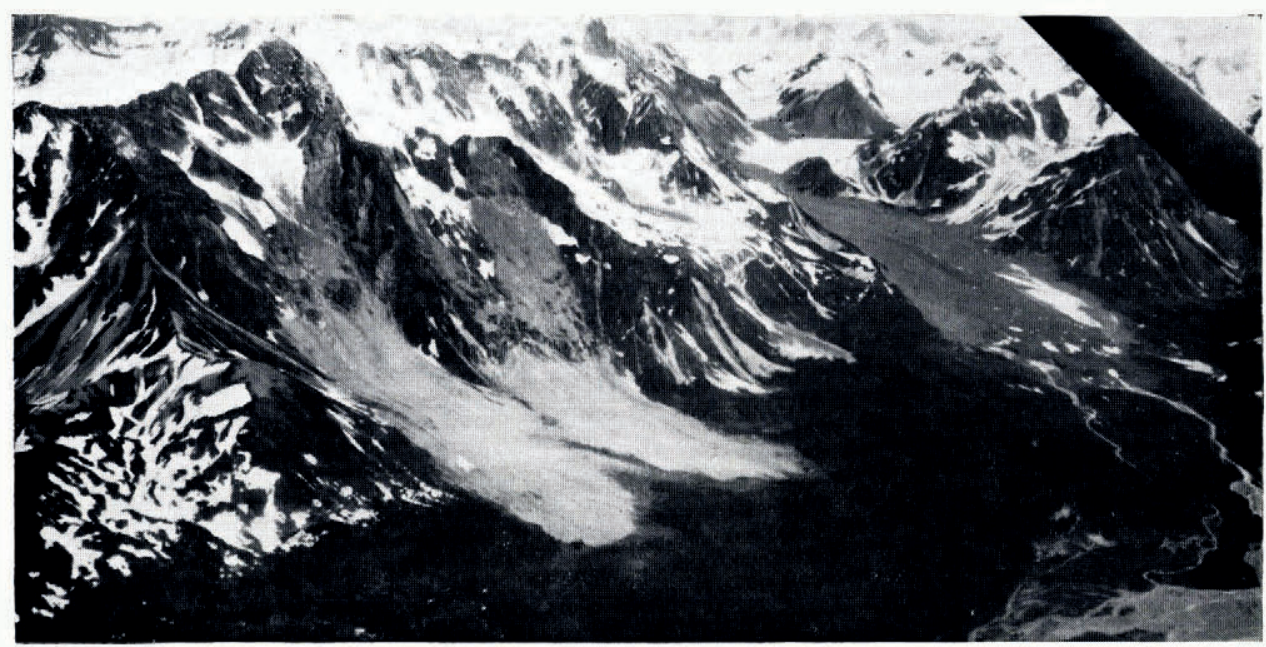

Fig. 5. Oblique aerial photograph of "Sioux Glacier" (right center) taken from above the terminal moraine of Martin River Glacier and viewed towards the north-north-east. Two large debris avalanches (center foreground) presumably occurred at the same time as that on "Sioux Glacier" (i.e. 27 March 1964). The medial moraine and former terminal debris of "Sioux Glacier" are characterized by slightly darker color. White patches in the terminal moraine area are snow. (15 June 1964)

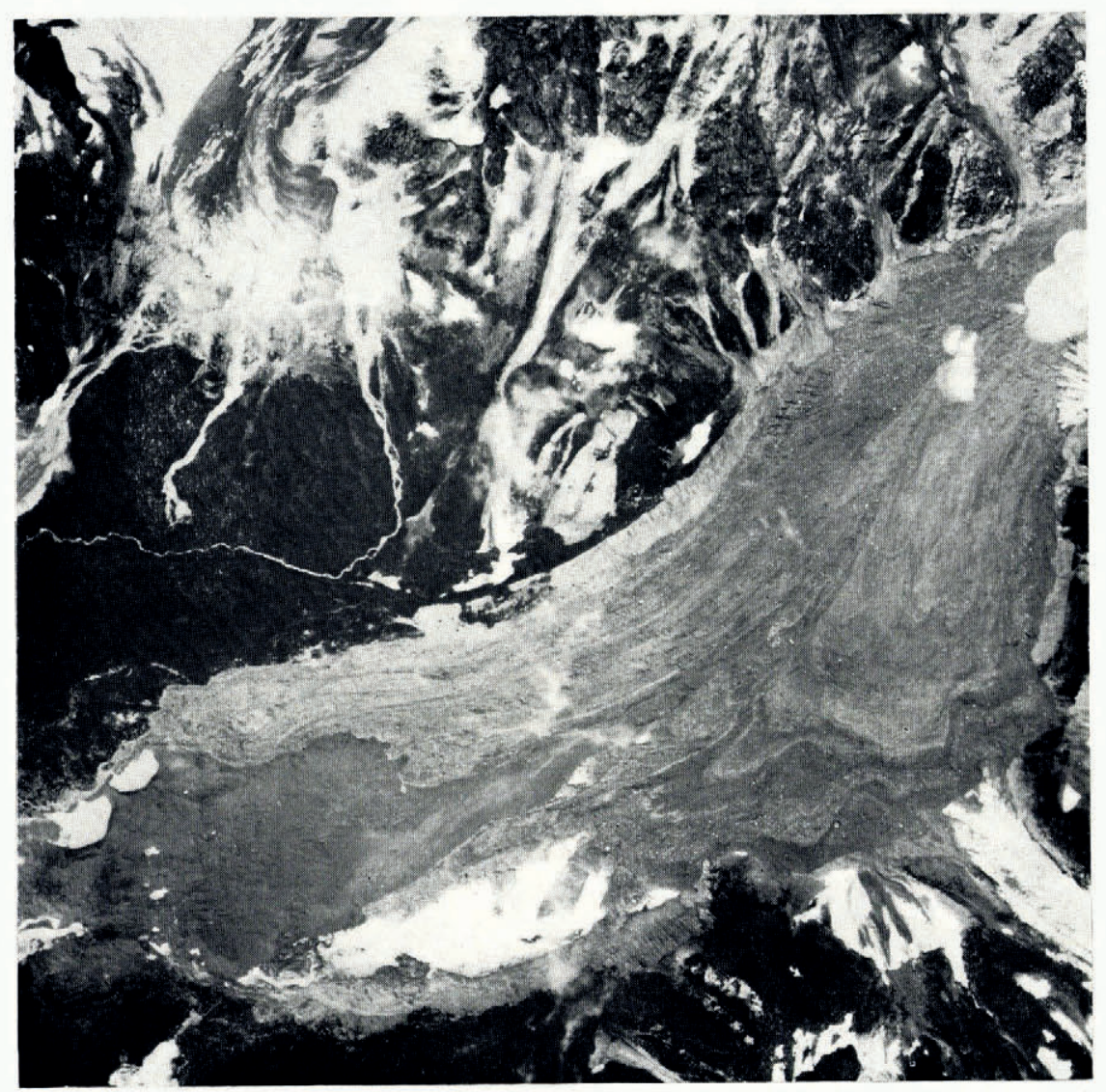

Fig. 6. Vertical aerial photograph of lower "Sioux Glacier" ( from I I, ooo ft. (3,353 m.) altitude). Rock debris from the 1964 avalanche is lighter in color than that on the medial moraine and the pre-1939 avalanche debris material. Rock material is estimated to average $5-5 \cdot 5 \mathrm{ft}$. $(\mathrm{I} \cdot 52-\mathrm{I} \cdot 68 \mathrm{~m}$.) in thickness. (Photograph by Austin Post; Exp. 239, Roll V648, U.S. Geological Survey; 24 August 1964) 


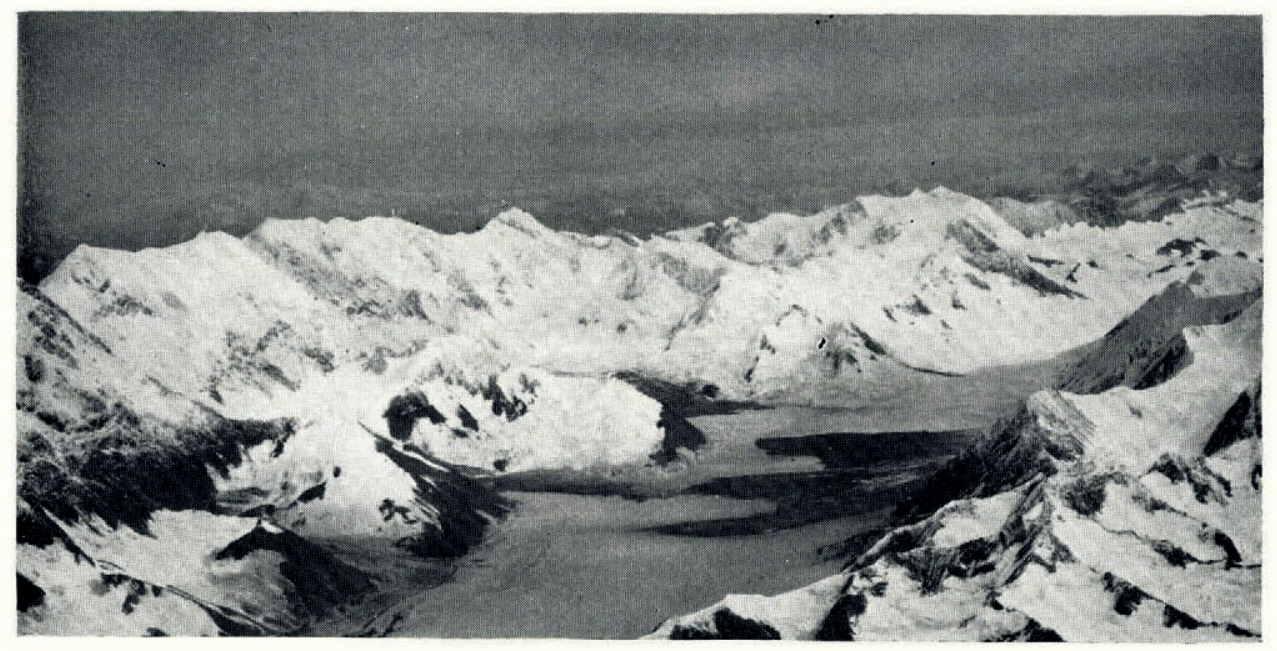

Fig. 7. Oblique aerial photograph of five large snow and rock avalanches on upper Martin River Glacier at about lat. $60^{\circ} 35^{\prime} \mathcal{N}$., long. ${ }^{4} 43^{\circ} 50^{\prime}$ W. (Photograph by Austin Post; No. K642-97, U.S. Geological Survey; 24 August 1964)

Society (personal communication) observed that approximately $25 \mathrm{ft}$. $(7 \cdot 6 \mathrm{~m}$.) of glacier ice were conserved by the debris avalanche on Sherman Glacier during the 1964 ablation season (data taken at the end of August 1964). Superglacial topographic inversions of the type described by Russell (Igor, p. I I2-2 I), Tarr and Martin (I9I4, p. 205-28), and Clayton (1964, p. I07-12) should contribute to the dispersion of the rock debris well up-glacier from the terminus. As the debris approaches the zone of maximum ablation, this mechanism will increase in effectiveness. Thus the lateral dispersion of material from medial moraines may be a minor factor in effecting complete coverage of the terminus of the glacier with rock debris and irregularities of subglacial topography need not be invoked to explain this condition.

The recognition of earthquake-triggered rock slides, rock falls, and snow and rock avalanches as an effective mode of delivery of superglacial debris is important. The ultimate stagnation of glacial termini which have become heavily coated with rock debris, may, when the possibility of rock avalanching is ignored, be interpreted as a response due largely to regional climatic changes. Also, the accumulation of large amounts of superglacial debris implies a period of time required to effect the accumulation, much greater in dimension, when the normal rates of mass wasting in a region are used as an index, than is the case when massive earthquake-triggered slides, falls and avalanches are recognized as a major source of the debris.

MS. received I 8 June 1965

\section{REFERENGES}

Clayton, L. 1964. Karst topography on stagnant glaciers. Fournal of Glaciology, Vol. 5, No. 37, p. 107-12. Russell, I. C. Igo I. Glaciers of North America. Boston, Ginn and Co.

Tarr, R. S., and Martin, L. 1914. Alaskan glacier studies of the National Geographic Society in the Yakutat Bay, Prince William Sound and lower Copper River regions. Washington, D.C., National Geographic Society. 